\title{
Sønderjylland 1927.
}

\section{Af Thade Petersen.}

\section{Grænsen.}

Sønderjylland, saaledes som det fremtræder efter Gransedragningen i 1920 har et $0 \mathrm{~m}$ fa $\mathrm{n}$ g af $359.114 \mathrm{ha}$, hvoraf 135,102 harer til Haderslev, 130,852 til Tønder, 79,012 til Aabenraa og 44,140 til Sønderborg Amt. $\mathrm{H}^{10}\left(\mathrm{~g}^{*}\right)$ ). For at bode paa en af de Vanskeligheder Grænsedragningen i 1864 forte med sig, bliver der imidlertid i Hygum Sogn taget 904 ha fra Haderslev Amt og lagt til Ribe Amt. (H. ${ }^{2} / 4$ ). Fra det forstnavnte Omraade stammer, efter hvad Dr. Alnor oplyser, 5136 af dem, der $i$ Krigen f ald t paa tysk Side, 3,09 pCt. af Befolkningen moll 3.8. fra den tyske Del af Hertugdommerne (Av. ${ }^{13} / \mathrm{s}$ ). Den danske Stats U d g ifter ved Grænsedragningen ongures - dog meget misvisende - til 435, 099,859 iKroner. (H. ${ }^{211 / 4}$ ).

Fær dsle n over Græunsen kræver nu mindre Opsyn. 35 Grænsegendarmer er opsagt til ${ }^{31}{ }_{4}$. (H. ${ }^{13} / 7$ ). I Furbindelse med den ny Gransedragning staar det forholdsvis store Antal Ansugninger fra Nordslesvig om dansk Borgerret, i 1927 1:2. (Av. ${ }^{19} / 1$ ).

Repræsentanterne for det danske Mindretal forlod i August sammen med de andre Mindretal i Tyskland Mindretalskonferencen i veneve, fordi Friserne ikke havile faaet Adgang til Konferencen. (H. ${ }^{25} / \mathrm{s}$ ) Om Mindretallenes Kaar ved den dansk-tyske Granse sagde W. Schücking iøvrigt i. Kabenhavn, at den Ordning, der her var truffet, opfyldte alle berettigede krav. (II. ${ }^{27} / 11$ ).

Grænsedragningens $R$ et $f$ a $r$ ig h e d er ogsaa i Aar ved flere Lejligheder bleven anerkendt af fremragende Tyskere. Saaledes skivier "Deutsche Zukunft", at den falder saa noje sammen med Befolkningens nationale Sindelag, som det i det hele er" tankeligt. (H. "/4). Et Ldtryk

*) $\mathrm{H}=$ Hejmdal, Av. = Flensborg Avis, $\mathrm{L}=$ Nordslesrigrsk Jandbrugs- og Mejeritidende, (ir. = Græuseragten $19: 27$. 
fur Tilfudshed med den kan oxsaa tindes i, at der fra tysk Sicle gennem Professor Scheel og Dr. Schifferer sattes et Arbejde i Værk for tysk-nordisk Samarbejde. (H. $\left.{ }^{10} / 10\right)$. Den paatmnkte tysk-nordiske Universitetsuge maatte dog opgives jaa Grund af tysknationalistisk Modstand. (H. 10/12). Udtryk for tysk Utilfledshed med Gransen har der dog heller ikke i 19:7 raret Mangel paa. Hindenburg talte i Flensborg om Nordslesvig som tysk Moderjord (Av. ${ }^{31} / \mathrm{s}$ ) og ved det tyske Gymmastikstavne i Flensborg taltes der om Udfald mod Gransen. (Av. ${ }^{\tilde{s}} / \mathrm{z}$ ). Pastor Schmidt angreb i Folketinget dansk Styre i Nor(slesvig men blev som sadvanligt grundigt vist tilbagre. (H. $\left.{ }^{15} / 10\right)$. Værre var imidlertid et Angreb af en dansk Mand, Prof. Farl Larsen, paa det danske Mindretalsstyre som planlagt Opsugningsiolitik. (H. ${ }^{24}$ 11. ${ }^{20}$ !1).

Til Craænsefremtoningerne kan endnu regnes Lidgivelsen af Dr. Alnors tyske Haandlog i det slesvigske Sporgsmaals Historie, der imidlertid or ganke uvidenskabelig. (H. $\left.{ }^{2+}, 10\right)$.

\section{Nationalt Liv ved Graensen.}

a) Dansk syd for gransen.

Antallet af dansktalende er ifulge den tyske Statistik af ${ }^{14}$ (25) siden 1910 gaaet ned i Flenshorg By fra 3706 til 1784, i Flenshorg lireds fra Tonder Kreds f'x $\$ 413$ til 1901. I alt var der nu 5709 dansktalende i syl- og Mollemslesvig. Deraf talte 1543 hegge Siprog. Ilele Antallet er efter det gaaet tilhage med 50 pCt. siden 1910. (HI. ${ }^{11}$ ). Men Arbejulet for Bevarelsen af Dandskheden swakkes ikke. Ved et Morde i Flenshorg sogtes et dansk samarbejde for Danskheden Syd for Gransen sat i Vark. (II. "15 11). Granseforeningen, hvis Arbejde mest ligger (ler, har 35,5k) Medlemmer, deraf 4966

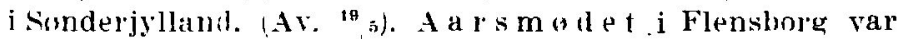
storre end i Fjor, 5okr til Friluftsmude. Dog har den slesvigske Forening mistet ?68 Medlemmer. Den har nu 4187. (Av. ${ }^{14}$ a). I et dansk I d $r$ a t s s t r ve i Flenshorg deltog Hold fra Flenshorg. Harreslev, Osterby Mark, Skovlund, Jaruplund, Talup og Slesvig. (Av. ${ }^{\circ}$ ). I April holdtes ogsaa et gult (iymnastikstavne i Flenshorg. (Av. ${ }^{20 / 4}$ ).

Endnu hav Folvidrene ikke faat den selvfolgelige Ret til selv at bestemme Burnenes I ndervisnings- 
sprog. (H. ${ }^{7}$ ). Af Indenrigsministeren faar de dog et velvilligt Svar med Hensyn til Skole og Presse. (Av. 1/10). Endnu mere betyder det virkelige Fremskridt, at Duborgsk ole n for 3 Aar faar Statstilskudet forhøjet fra 5 M. til 40 M. pr. Barn. (H. ${ }^{10}$ "1). Den har 325 Elever. (Av. 8/5). 19 tog Afgangseksamen i 1927. (Av. 3/4). I J a r u p l und indviedes en ny dansk Skole. (1Av, ${ }^{29 / 3}$ ). I Marts sattes en dansk Ungdomsuge i Værk flere Steder. (Cirv. 121).

For den danske Menighed i Flensbnrg er det af stor Betydning, at den har fact overladt Helligaandskirken, som blev ind viet ${ }^{28 / 8}$. (H. ${ }^{29 / 4}$ ). I MAnsgar dobtes der $\mathbf{i}$ Aarets Lob 40 Børn, 109 blev konfirmeret, der var ca. 1500 Nadvergaster. (Av. $\left.{ }^{17} / 5\right)$.

Fra Bogsamlingen i Flensborghus er udlaant 45,153 Boger, og Lasestuen har været besøgt af 19,943. ( $\mathrm{H}$. 1/10). Mod Slutningen af Aaret fik "Flensborg Avis" endelig Byens Kundgorelser, derimod faar "Der Schleswiger" dem ikke. (Ar. ${ }^{25}{ }_{12}$ ). En slesvigsk $K$ red itforen ing oprettes i Flensborg. (H. ${ }^{211}{ }_{12}$ ).

\section{b) Tysk syd for frop nen.}

Paa den nationale Konto faar og kræver Tyskerne stadig store Midler til Brug i Grænseegnene. Paa et Møde i "Landbund" i Hanved krævedes der tysk Kolonisation af Stroget op mod Grænsen. (H. ${ }^{22} / 2$ ). Provinslanddagen giver 200,000 M. til et "t ys $\mathrm{k} \mathrm{H}$ u s $\mathrm{i}$ Flensborg. (H. $\left.{ }^{5} / 4\right)$. Af 25 Millioner til tysk Grænsearbejde faar Slesvig-Holsten 3,5. (H. ${ }^{12} / 7$ ). De $ø \mathrm{k}$ on $\mathrm{om}$ is k e Forhold er vanskelige dernede. Flensborgs Budget er paa 11 Mill. M. (Av. ${ }^{10} / 3$ ), og den laaner 7 Mill. til 9 pC.t. (Av. ${ }^{3} / \mathrm{s}$ ).

Flere af de Mænd, der indtog en fremragende Plads i tysk kulturelt Arbejde dernede, har trukket sig ud af det. Henningsen traadte tilbage som Forstander for Højskolen i Rendsborg, og Trænckner forlod i al Stilhed Landet, skuffet. $\left(H .{ }^{10} / 11\right)$. Professor Scheel nedlagde sit Hrerv som Formand i Schleswigholsteinerbund (H. ${ }^{28} / 11$ ) efter at have lidt store Tab red den nationalistiske Bedrager Kleinroden. (H. ${ }^{10} / 11$ ).

c) Tyski Nordslesvig.

Til Trods for, at den tyske politiske Ledelse holder haardt paa, at Tyskerne skal blive her i Landet og gøre 
Krav paa alle de Rettigheder, de kan faa, flytter der dog studig en Del af dem bort. Alene fra Tonder skal saaledes i kort Tid 8-10 Familier være flyttet Syd paa. (Av. $4 / 10$ ). Fri for indre Brydninger er de heller ikke. I Maj sprængtes deres $V$ æl lgerforening i Haderslev over spurgsnaalet om Grænseflytning til Kongeaaen. (H. ${ }^{24} / 4$ ). Dryanders udæskende Tale paa Knivsibjerg holdt heller ikke alle for betimelig. (H. ${ }^{27} / \mathrm{s}$ ). Senere maatte "Apenrader Tageblatt" aabent indrømme, at der var en $R$ evne $i$ Mindretallet. (H. 1/7). Stærkere kom det frem, da Raben angreb Pastor Schmidt (H. ${ }^{12} / 7$ ), og Aarsmødet i Haderslev med 166 Stemmer mod 4 forkastede $H$. C. Hansens og Rabens Forslag om offentligt at gøre Kongeaagrænsen til Maal for tysk Politik. (H. ${ }^{27} / \%$ ). Da Kongeaatyskerne udsendte andet Nummer af Die Königsau var imidlertid flere Navne udgaaet af deres Opraal. (H. "'11).

Ellers benytter de ivrigt de Rettigheder, de har. Virksomst er de næsten paa $\mathrm{k}$ irkeligt $\mathrm{Om} \mathbf{m}$ a a de. I Januar fremkom deres Fremmedmenigheder med et Ønske oin at faa Kidskelund skole til Guistjenester, skant der fra Folkekirkens Side aarlig holdes 15 tyske Gudstjenester i Sognekirken. Præsten og Sogneraadet afslaar det. Det rar da heller ikke Folk i Kidskelund, der onskede det. (H. ${ }^{21}$ 1). De tyske Fremmedmenigheder, som i Almindelighed fejlagtigt kaldes Frimenigheder, holdt i Marts Gudstjenester 25 Steder i 19 Sogne mod Aaret før 13 i 12 Sogne. (H. ${ }^{22} / 3$ ). En ny saadan Menighed dannedes i Graasten med Wassner som Præst. (H. ${ }^{10} / 4$ ). I November holdt Tyskerne saavel fra Fremmedmenighederne som fra den danske Folkekirke et folles Menighedsmode i Aabenraa, hvor Braren og Lausen advarede imod Splittelse, mens Pastor Horstmann betegnede den kirkelige Tilstand i tysk Tid som næsten ideel. (H. $\left.{ }^{12}, 11,{ }^{14} / 11,{ }^{21} / 11\right)$. Tidligere havde han paastaaet, at Præsterne den Gang holdt sig neutrale i politisk Henseende.

I S. Vilstrup indviedes en tysk $\mathrm{Pr}$ i vat $\mathrm{s}$ k o l e med 49 Elever. (H. $\mathbf{8} / \mathbf{3}$ ). Kort Tid senere forlangte deres politiske Ledelse Eksamensret for deres Realskoler, Adgang for tyskuddannede Lærere og Refusion af Udgifterne for de Forældre i Tonder, der sender deres Burn i den tyske Realskole i Stedet for i Statsskolen. (H. $\left.{ }^{15 / 3},{ }^{18} / 3\right)$. Ogsaa Roddling fik en tysk Privatskole med 20 Elever. (II. $/ 5$ ).

I Sønderborg aabnedes et tysk Bibliotek (H. $7 / 11$ ). Den tyske Haandhog i det slesvigske Sporgsmaals Histo- 
rie giver en overfladisk og vildledende skildring af Marinus Hansens Forhold. (H. ${ }^{8 / 11}$ ).

Fn Langelænder, Lggert, i Felsted, aer havile en Gaard i Forpagtning, demonstrerede ved at save F lagstange $n$ red Gaarden om og prale offentligt af det. ( $H$. $\left.{ }^{19} / 1,{ }^{24} / 1\right)$. Ved et tysk Made paa Jejsing Banke demonstreres der med sl.-holst. Flag. (H. $\left.{ }^{30}{ }^{\prime} s\right)$.

Corn. Peterse $n$ faar ved et Mode i Aabenra ot Tusinde Mennesker til at henvende sig til "vor linge og llertug“ og bl. a. kræve Selvstyle for Nordslesvig. (H. ${ }^{1 / s}$ ). Ilan fik senere Audiens hos liongen, men henvistes til Lovgivningsmagten. (H. $\left.{ }^{15} \mathrm{~s},{ }^{16}, \mathrm{k}\right)$. Wan er i Pengetrang. (H. ${ }^{20} / \mathrm{s}$ ).

Pastor schmidt ex jæunlig fravarende i Folketinget. (H. ${ }^{10} / 7$ ).

I Juli aflagde Prasteseminariet i Preetz B e s o g i flere nordsl. Byer samt Askov og Ribe. (H. ${ }^{2 /} / 7$ ).

Tyskerne i Logumkloster vil ikke lade Burnene gaa til G y m a s tik i Forsamlingshuset. (Av. 1/11).

d) Danski Nordslesvig.

Paa F o re $n$ ings live ts Onuraade har der vart livligt Rore med glædelig Stilen mod Samling af Krafterne. Skoleioreningen fik Stıtte ved Genoprettelsen af S. S. i Kolding og maaske lignende andre Steder. (H. ${ }^{17} / 1$ ). Skole-, Sprog- og Granseforeningen samt danske Foreninger Syd for Gransen vedtog at samles hvert Aar for at drofte fælles Opgaver. (II. ${ }^{31} / 1$ ). Senere nedsatte de et Udvalg paa 6 Medlemmer til Fremme af Samarbejdet. (H. 12/10). Sprogforeningen havde ved Nytaar 2486 Medlemmer og har uddelt 11,439 Bind. Skoleforeningen har 12,546 Medlemmer i Nordslesvig, og 3912 i det wrige Land. Den har storttet 308 Elever og givet 31,0/0 Kr. til Ungdomsskole Syd for Gransen. (H. 1/7). Dansk Samfund for Sonderborg havde ${ }^{23} / 8900$ Medlemmer. (H. $\left.{ }^{24}{ }^{*}\right)$. Sonderjydsk Idrætsforening har haft Tilgang af 16\$4. (II. ${ }^{14}{ }^{3}$ ). Sonderborg Borgerforening holder 70 Aars Jubilaum. (II. $6 / 4$ ).

Et nyt For's a m ling $\mathrm{s}$ h u s indviedes i Uge. (H. ${ }^{15} \mathrm{r}$ ) ). "Frej« i Christiansfeld solgtes for $41,000 \mathrm{Kr}$. (H. ${ }^{5 / 12}$ ) En Basar til stotte for Tonderhus gav jo(n) Kr. (Ar. $"$ $8 / 2,{ }^{15} / \mathbf{z}$ ). Højskolehjemmet i Haderslev holdt 25 Aars Jubilaum. (H. $\left.{ }^{201}{ }_{1},{ }^{25},{ }_{1}\right)$. I Tonder indrettedes et dansk liontor. (H. ${ }^{21 / 11}$ ). 
Af $M$ o d e r skal sarlig nævnes de mange Afstemningsfester (H. ${ }^{11} / 2$ ) og Genforeningsfester (II. ${ }^{16} / 6$ ) og et stort nationalt L'ngdomsmade i sonderborg. (H. $\left.{ }^{24} / 10\right)$ og et to Dage's nationalt stavne samme Steds ${ }^{23}$ g og ${ }^{24}$ y.

Som sadvanlig aflagde Kongen et $B$ es $n g$ hernede (II. ${ }^{2: 3}$ 5) og i September var $3(h)$ sonderjyder paa Besug $i$ Kiblueulavn (H. $\left.{ }^{23} / 4\right)$.

I Tonder ankede de danske Byraadsmedlemmer over, at Borgmesteren forelagde Sagerne pa a Ty sk. (Av. ${ }^{12} / 2$,

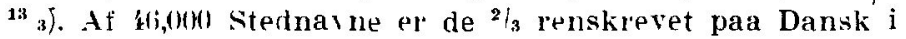
Jurlehogerne. (II. ",, ).

\section{Politik.}

I lolitikken har kun selvsty reraret gjort sig bemarket. (iaardejer hylling blev smidt ud fra »Bondens Selvstyre «s Generalforsamling. (H. $7 / 1$ ). En af Comelius Petersens vilde Planer var at danne en Selvstyreforening med : Kroners Aarsbirtrag. Den skulde saa red Trangssalg kothe Medlemmers Gaartle for 1 krone og udlaane dem til Ejerne, hris fiald skulde sættes ned. Enhver, der paa Statens Vegne gik ind $i$ en saadan ciaard, skulde erklares for fredlos. (H. ${ }^{13}{ }_{1}$ ). Processen mod de 3 Selvstyrelojtnanter So 19:26) begyndte ${ }^{17}$ i Sonderhorg. De blev frikendt. (1I, ${ }^{17}{ }_{1},{ }^{18}{ }_{1}$ ). I Marts kom Cornelius Petersens sag for Fornarmelse mod stauning for Howjesteret. (H. ${ }^{10 / s}$ ).

\section{Samfundsforhold.}

Folketallet er i javn on end ikke stark Vækst. Det var uden Militar

\begin{tabular}{|c|c|c|}
\hline & $19: 0$ & $19: 2 \tau$ \\
\hline i Hadersler & 13,211 & 14,3018 \\
\hline i Aabenraa & 7,$831 ;$ & $8,1 i 27$ \\
\hline i Sonderborg & $\tau, 760$ & 10,281 \\
\hline i Tonder $(19: 1)$ & $.0,015$ & $5,5,511$ \\
\hline
\end{tabular}

Fulselshyppigheden er hetydelig stmre end i Byerne $i$ det ovrige Land, men Doxdeligheden er ogsaa meget storre, dog $i$ stadig Aftagen siden Genforeningen. Fidselsoverskulllet er i Hadersley og Aabenraa rokset starkt fra 192:2 til $2 h$, i sonderborg lidt; i Tonder or det sunket lidt. (II. "1' ${ }^{\prime 2}$ ). I Loblet af $19:$ i sank Folketallet $\mathrm{i}$ Tonder med 
144 (Av. ${ }^{22} / 11$ ) mens det i Haderslev steg med 21: (H. "12). Til Amerika u d va n d re de der 1864-1914 30,010 Sunderjyder. (H. $\left.{ }^{26} / 1\right)$. Et kobenhavnsk Forsog paa at danne en Koloni af Thyboer paa Tonderegnen mislykkedes. (H. $4 / 4)$.

Derimod skrider Udstykningen ellers godt fremad. ( $H$. $\left.{ }^{28} / 1,{ }^{15} / \mathrm{s}^{16} / \mathrm{s}, 4 / 11,{ }^{25} / 11,20 / 12,{ }^{20} / 12\right)$. I alt oprettedes $70 \mathrm{ny}$ Husmandsbrug $i 1927$, ca. 40) paa tilsammen ca. 3000 ha siden 1922. (H. ${ }^{31} / 12$ ).

Mod Slutningen af Aaret var Arbejdslos heden som sædvanlig igen starkt stigende. Den omfattede lige til Jul 1995 i Haderslev, Aabenraa og Tonder Amter eller 443 flere end 14 Dage for. $\left(H .{ }^{10}{ }_{12},{ }^{24} / 12\right)$. I disse 3 Amter svarer den omtrent til de norrejydske, derimod er den $\mathrm{i}$ Sonderborg Amt betydeligt hojere. (IH. 16/2). I Haderslev lod en Del arbejdsløse sig desværre henrive til et Overfald paa Medlemmer af Byraadet. (II. ${ }^{16} / 2,18,2,20 / 4$ ).

Sundhedsforholdene lader endinu en Del tilbage at onske. Sygeligheden er storre i Sonderjylland end $i$ det ovrige Land. Sygekasserne er derfor vanskeligt stillet (H. ${ }^{7}{ }_{4},{ }_{4}^{4}$ ). Aabenraa Amt har den største Tuberkulosedodelighed i Danmark. (H. $\left.{ }^{7 / 6}\right)$. Af Sygeplejeforeninger er her 19. (H. ${ }^{23 / 4}$ ). I Haderslev Amt udvides Sygehus e ne for $700,(\mathrm{k}) \mathrm{Kr}$. (H. $\left.{ }^{2 \%} / \mathrm{s}^{25}, 5\right)$ og Haderslev Byes for 28,000 Kr. (H. 10/12) og i Aabenraa vil Tuberkulosehosuitalet blive fortsat. (H. ${ }^{24}{ }_{11}$ ). Centralforeningen af $\mathrm{Sy}$ gekasser i Sanderjylland omfatter 115 med 71,819 Medl*mmer. (H. ${ }^{26 / 7}$ ). De onsker Sygehustaksterne nedsat. (H. $\left.{ }^{27} / \mathrm{p}\right)$. Den nordsl. Kvindeforening har et $\mathrm{H}$ vil e h j e m, to Børnehjem og et Sinkehjem. (H. ${ }^{30} / 5$ ).). Paa H els e h j e mmet var der 1926318 Børn, deraf 96 fra Mellemslesvig. ( $H$. 2:/s). Det fik en ny .Bygning overdraget af Sonderj. Fond. (H. ${ }^{12} / \mathrm{s}$ ). Nordslesvigsk B orneas y l holder 50 Aars Juhilæurn (H. ${ }^{4}$ ) og faar en Gave paa $25(10 \mathrm{Kr}$. (H. 16/4). To tyskuddannede $\mathrm{T}$ a $\mathrm{n} d \mathrm{l} \boldsymbol{\mathrm { ag }} \mathrm{e} \mathrm{r}$ faar Ret til at praktisere. (H. ${ }^{25} / 5$ ). Ho mo pat er n e kræver det ogsaa. (H. ${ }^{27} / 5$ ).

Ka $\mathrm{ationister}$ beder om, at Hjælpen til Landmandene ogsaa maa komme dem til gode. (H. $\left.{ }^{12} / 1\right)$. Sonderjydsk Brugs forenings Konkursbo bliver endelig opgjort, og Kreditorerne faar deres Tilgodehavende. (H. ${ }^{2 k} / \mathbf{s}$ ). Fattiggaardene staar omtrent tomme. I Tonder Amt er der 17 med 20 Alumner. (H. ${ }^{14} / 7$ ).

Lo Herreds Brandforsikring har blandt sine 2:018 Forsikıede haft 21 Brandskader til 108,202 Kr. (Av. 
$5 / 3$ ). Det brænder hyppigst i Sinderjylland og i Ringkøbing Amt. (H. ${ }^{27} ;$ ) . Med Hensyn til Brand vær $n$ er Sønderjylland godt stillet. Det forste frivillige dannedes $i$ Sønderborg 1877. (H. \%). Det har nu 333 Medlemmer. (H. ${ }^{12} / \%$ ).

\section{Erhverv og Okonomi.}

a) L a nd brug.

J u v re dige t paa Romo blev i 1927 saa vidt færdigt, at det kunde beskytte Engene mod Havet. Endnu en Gang blev de dog oversvommede inden det sidste Hul lukkedes, nemlig ${ }^{23} / 4$. (H. ${ }^{25} / 4$ ). En Stormflod i Oktober 26 havde beskadiget det en Del. (H. ${ }^{3 / s}$ ). Med dette Dige er det sidste Stykke af egentlig Marsk i Sonderjylland beskyttet. Havnebydiget, der er færdigt, har kostet 131,937 Kr. og skal endnu forstærkes for $20,000 \mathrm{Kr}$. (Av. ${ }^{17} / 3$ ). Di. gerne paa Rømu beskytter nu tilsammen 1163 ha. (Av. ${ }^{15} / \theta$ ).

I Foraaret toges rigtig fat paa Arbejdet til A f v a nd ing af Marsken ved Tonder. (Av. ${ }^{2 y / 4}$ ). Uldfurt var ved den Tid allerede Højer-Emmerlevdiget $\left(\mathrm{Av} .{ }^{20 / 4}\right)$ og en Del af Arbejdet i Sejersbækdalen. (Av. ${ }^{8} / 5$ ). Det viser sig, at Vidaaen ikke kan bruges som Afvandingskanal, da Jorden omkring den er for los. (Av. ${ }^{1 / \eta}$ ). Vandstanden vil her blive holdt $1 \frac{1}{2} \mathrm{~m}$ under Terrænet. I det Øjemed skal $75 \%$ af Nedharsmængden pumpes ud. (Av. ${ }^{10} / 12$ ) Af D r $æ n$ planer i Tinder Amt er der udarbejdet 68 paa 380 ha,

- og meget af dette fuldført samtidig med andet tidligere planlagt. (L. 1927 S. 167).

$\mathrm{L}$ a $\mathrm{n}$ d $\mathrm{v}$ in $d$ inge $\mathrm{n}$, der siden Bygningen af Dæmningen til Sild, har været stor Nord for denne (Av. ${ }^{30} / 7$ ) fremkaldte Tanken om en lignende Dæmning til Røınø, som dog Sagkundskaben maa fraraade. (Av. ${ }^{13} / 11$ ). Paa hele Sønderjyllands Vestkyst har Vindingen i de sidste 700 Aar været større end Tabet. (H. $\theta / 5)$.

Træplantning skrider godt fremad paa Vestkysten. 3 Plantager paa tilsammen 24 ha er opstaaet (H. $7 \%$ ) og senere efterfulgt af endnu 2 paa ca. 15 ha. (Av. $8 / 8$ ). Den største bliver dog anlagt paa Abild Hede, hvor Tøn. der By købte 60 ha for $6750 \mathrm{Kr}$. til Tilplantning ved Hjælp af Arbejdsløse. (Av. ${ }^{20} / 8,1 / 10,25 / 10,1 / 11$ ).

Af Sonderjyllands 386,788 ha er 286,000 under $\mathrm{K}$ u lt u r. (H. ${ }^{12} / \theta$ ). I 1926 faldt hele Udvidelsen af Danmarks dyrkede Areal, 5Co\% ha, paa Sonderjylland. (H. ${ }^{7} / 11$ ). I Ma:- 
sken Syd for $\mathrm{H} \iota \mathrm{jer}$ anlagges en Forsogsgaard. (Av. ${ }^{2}{ }^{7}$ ).

Af $s$ lagterierne har det i Sonderbory haft storst Vanskelighed at kxmpe med. En Del af dets Gxeld maatte overtages af Indelshaverne, hvorved dets Regnskab forbedredes med 1(K-12(0,(K) Kr. arlig. (H. $\left.{ }^{5} / 1\right)$. Det har i 1926 behandlet $58,6 \pi 8$ Svin, 20,000 flere end i 1925. (H. 31/3). Graasten Slagteri har modtaget $35,8 / 5$ Svin. Det har nu 801 Andelshavere. (H. ${ }^{10}{ }_{2}$ ). Vojens har slagtet 20.270 , (H. 14/3), Aabenraa, 56,811.r. (H. " ${ }^{12}$ ). Skarbak $23,5,51$, Tonder 25,151. Bylderup-Bor 25,146 (Medicinalberetningen for Tonder Amtslægekreds for 14:T).

Af Fornyelser i M ejerierne er i 19:6 sket en $\mathrm{Ny}-$ bygning i Uge, Omlygning i Bylderup, Udvidelse i Arnum, ny Bestyrerbolig i Ketting. (H. $\left.{ }^{0} / 1\right)$. Tekniske Forbedringer er kun faa og smaa. (L. 19:2 S. 27). Malkemængden er steget $34 \%$. Smorret med ca. $5 \%$. (H. ${ }^{11 / 3}$, L. 1927 S. 10). Paa den jydske Mejeriulstilling i Fredericia naaede Haderslev Amt hojest op. Derefter sondorborg Amt. Aalenraa er Nr. is og Tonder det daarligste.

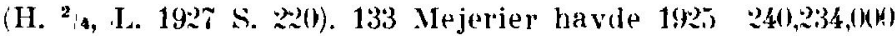
kg Mælk, 1926 244,980,000). (L. 1927 S. 158).

Sonderjydsk Smmreksportforening solgte $19: 649,776$ Iritler, deraf 39,5) til Tyskland, (H. $\left.{ }^{34}, 1\right)$. Haderslev Smor-

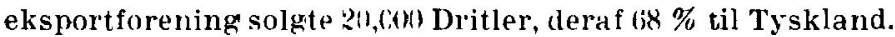
(H. 4/2). I 3/4 Aar solgte St)nderjydsk Smoreksportforening 30,477 Dritler. Mangden var steget med rigelig $10 \%$. (II. $\left.{ }^{24} / 10\right)$. Andelssmmreksportforeningen i Sonderborg i 11 Maaneder 4t,707 Dritler (1:01 Fremgang). (H. $\left.{ }^{7} / 11\right)$. Den i Haderslev i 9 Maaneder 16,31) Dritler (H. 1\%/11) og Tonder Smorsalgsforening solgte 918: Dritler. (Av. ${ }^{27 / 11}$ ).

Sonderjydsk Fallesledelse af rodt d a n sk Malke$\mathrm{k} v æ \mathrm{~g}$ har $\mathrm{nu}$ virket i 6 Aar. Antallet af kontrollerede Koer er $\mathrm{i}$ den Tid tidoblet, nemlig 2246 . Der er $500 \mathrm{~kg}$ Malk Fremgang pr. Ko og : : $\mathrm{kg}$ Smor. Medlemsantallet er nu 220. (H. ${ }^{10 / 1}$ ). Sonderborg Amt staar som Nr. 1 blandt de jydske Amter med Hensyn til Mælkemangde. Dog er Fedtprocenten endnu for lille. (L. 19:7 S. 6).

Fallesledelsen af AVl af hollandsk Malkek v $æ$ g har haft 1459 kner under Kontrol. Jeres Ydelse er sidste Aar gaaet frem med $13 \mathrm{~kg}$.Mælk, 0,0; \% Fedt og $1,8 \mathrm{~kg} \mathrm{Sm}$ (r) pr. Ko. (H. $\left.{ }^{17} / \mathrm{s}\right)$.

A $n$ tallet a $\mathrm{K}$ o e $\mathrm{r}$ er siden 1920 steget med $22 \%$. hrilket dog jkke naar stigningen i hele Danmark i samme Tid, $24 \%$. Mens det fra 24 til 25 gik $0,3 \%$ tilbage her i 
Sonderjylland, er det fra 25 til 26 steget fra 96,004 til 100,906. Studeantallet er taget starkt af. Endnu er dog Mælkeproduktionen langt tilbage: kun 792 kg pr. ha mod 1227 i hele Landet. Sønderborg Amt staar dog med sine $1557 \mathrm{~kg}$ pr. ha langt over Landsgennemsnittet og er det rigest ydende i hele Landet. Til Gengald er Tønder Amit det daarligste (I. 1927 S. 202). Antallet af Køer pr. ha er da ogsaa for lille hernede nemlig $30 \bmod 43$ i hele I.andet. Ogsaa her staar Sonderborg Imt godt nemlig med 50 mens Svendborg Amt som det bedste i hele Landet har 59. (L. 1927, S. 61). Koantallets Vakst er fortsat ogsaa ind i 1927. Den 15. Juli var det steget til 105,055. Af Hornkvæg var der $\mathrm{i}$ det hele 296,6 622 , af Heste 34,875. (H. 7/10).

Mund- og Klovsygen ophorte i Maj. (H. ${ }^{22 / 11}$ ). En Del Køer er derimod bleven slaaet ned paa Grund af Yvertuberkulose. Af disse fandtes de $25 \%$ i Tander Amt. (H. ${ }^{13} / 12$ ).

b) Industriog H a n d vark.

Det meste ny paa Industriens Omraade er foregaaet i Elektricite tsforsyningen. Paa Hojspandingsværket er Forbruget i 1926 steget stærkt, med $25 \%$. Det har frembragt $6,769,450 \mathrm{kwh}$ og afskrevet $815,(100 \mathrm{kro}$ ner paa Anlagskapitalen. (II. ${ }^{7} / 3$ ). Sonderborg og Aabenraa Amters Elektricitetsforsyning har ligeledes haft Fremgang, $9 \%$ til Lys og 21,5 \% til Kraft til Landbrug, 1,i $\%$ til Haandvark. (H. $\left.{ }^{15} / \mathrm{s}\right)$. "Sonderjyllands Vestkyst" har haft 67010 Fremgang i Salget af Kwh (Av. $\left.{ }^{13} / \mathrm{s}\right)$ Haderslev Næs' Elektricitetsselskab har faaet $17 \%$ foraget Tilslutning. (H. $\left.{ }^{12} / 4\right)$. Tyrstrup Herreds har solgt Strøm for 144,195 Kroner. (H. ${ }^{28 / 3}$ ). Af Betydning har det ogsaa va. ret, at der opnaaedes Forlig mellem Hojsparndingsvarket $o g$ Værket i Haderslev. (H. ${ }^{2}$ is, ${ }^{12} / \mathrm{s}$ ). Ligeledes at Højspændingsværket skal levere hraft til Afvandingen ved T^rnder til 60,000 Volt. (H. ${ }^{30} / 11$ ).

Ellers kan nærnes, at Sonderborg () l j e f a b r i k nedskriver $\sin$ Aktiekapital fra $8(0),(5) 0$ til 40,040 og udvider den derefter til 1,125,0c0) (H. ${ }^{22}$ a) og . Iktiebryggeriet i Tonder har opnaaet $14,699 \mathrm{Kr}$. Overskud. (Av. ${ }^{20 / 3}$ ).

c) Handelog skibsfart.

Havneindtagterne i $1925: 20$ var i Haderslev $202,000 \mathrm{Kr}$. i Aabenraa 208,5(0), i Sonderhorg 275,(10) Kr. (H. 5/4) Hav- 
nedybden er i Haderslev 6,5, i Aabenraa og Sønderborg 7,5 og i Graasten $5,0 \mathrm{~m}$. (Av. ${ }^{15} / 6$ ). Der indgik i April Kvartal 27 i Haderslev Havn 653 Skibe, i Aabenraa 366, i Sønderborg 996, i Graasten 822. (H. ${ }^{22} / 2$ ). I Juli Tivartal var Tallene 676, 380, 1146 og 951. (H. $8 / 12$ ). Færdslen paa Aabenraa Havn er i Voksen. (H. ${ }^{31} / 12$ ). Selv i den lille nys udvidede Havn ved Augustenborg indgik der i 1925 488 Skibe. (H. ${ }^{22} / 7$ ). Fra Graasten Havn, der holdt 70 Aars Jubilæum $8 / 3$ (H. $8 / 3$ ) er der betydelig Kvægudforsel, undertiden 5-600 Stykker om Ugen. (HI. $7 / \mathrm{s}$ ). Derimod maatte Graasten Paketfart likvidere og udbetale $25 \%$ til Aktionærerne. (H. ${ }^{30} / 4$ ).

Ved Aabenraa Havn fuldførtes et $\mathrm{T}$ a $\mathrm{nk}$ a $\mathrm{n} \mathbf{\mathrm { g }} \mathrm{g}$ til $2400 \mathrm{kbm}$ Olje. (H. 8/4). Ligeledes er der anlagt et saadant ved Tonder til $150 \mathrm{kbm}$. (Av. ${ }^{11} / \mathrm{s}$ ). Tønder glæder sig i det hele over voksende Omsætning. (Av. $\%$ ) I Haderslev sluttede de to Trælasthandler, Hansborg og Haderslev Trælasthandel, sig sammen. (H. $\left.{ }^{10} / 10\right)$.

\section{d) Pengevæsen.}

I September 1927 dukkede en tysk Kreditanstalt under Ledelse af Advokat Vogelgesang i Haderslev op som en ny Faktor i sønderjydsk Pengevæsen (Se Sonderj. Aarb. 1927 S. 301). Det viste sig snart, at den var tænkt som et Kampmiddel mod Danskheden. Ikke alene laante Hr. Vogelgesang ret rigeligt Penge ud til Tyskere og indforte Forkwbsret paa deres Ejendomme, men han hindrede ogsaa danske Folk $i$ at købe Gaarde. ( $\left(H .{ }^{17} / 1\right)$. Han antoges at have 5 Millioner M. til Raadighed (H. $\left.{ }^{18} / 1\right)$ og arbejdede især i Grænsedistriktet. (H. ${ }^{24 / 1}$ ). Han vilde dog ikke vedgaa, at hans Arbejde var danskfjendtligt. (H. ${ }^{27} / 1$ ). Han sagdes at have 1500 Ansagninger liggende. (H. ${ }^{31} / 1$ ). Formaalet med Virksomheden sagdes at være at finansiere Nordslesvig i Labet af 10 Aar, for saa at trække det til Tyskland. (H. ${ }^{2} / 2$ ). Vogelgesang selv sagde ved Lejlighed: "Vi kan ikke finde os $\dot{i}$, at rigsdanske kommer her ned og køber Gaarde. Om 10 Aar har vi selv Ungdom nok til at

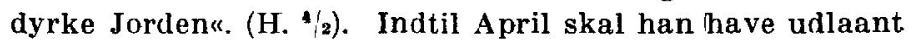
4 Millioner. (H. $8 / 2$ ). Han giver ogsaa Laan til tyske Studerende mod at de lover at soge deres Virksomhed i Nordslesvig. (H. ${ }^{15} / 2$ ). $1 / 4$ skal han have udlaant $5 \frac{1}{2}$ Millioner som han skal have faaet fra Thüringer Bank. (H. 1/4). Hans Aktiekapital udvidedes snart fra 45,000 til 495,000 Kroner, 
og Ahlmann i Kiel og Ohrt i Flensborg traadte ind i Bestyrelsen. (H. ${ }^{21}$ 4). I Maj overtog han Raifeissenkassen i Tinglev. (Av. ${ }^{10 / 5)}$ ). Fra $1 / 4 \ldots 15 / \mathrm{s}$ udlaante han $280,0 \mathrm{CO} \mathrm{Kr}$. til 45 Laanere. (II. ${ }^{18},{ }^{10 / 5}$ ). Sarlig stort blev Udlaanet $i$ Maj nemlig 663.(Kk), mod 22,000 i April. (H. $4 / 8$ ). En af Folgerne af hans letsindige Laanepolitik var, at han maatte overtage Skovgaard ved Aabenraa for $109,000 \mathrm{Kr}$. (H. ${ }^{23}{ }_{6}$ ). Med Maj havde Udlaanet forelobig kulmineret men ${ }^{1}$ a var det $\operatorname{dog} i$ alt steget til $1,048,255$, fordelt paa 143 Laan. (H. ${ }^{25} / \mathrm{s}$ ). I August kom yderligere $77, \pi 00$ til paa 15 Laan. (H. ${ }^{1 / 9}$ ), i September 12 Laan paa $38,820 \mathrm{Kr}$. (H. ${ }^{6 / 10}$ ), i Oktober 13 paa $7 \tau . \times 10 \mathrm{Kr}$. (H. $/ 11$ ) og i Novbr. og Lecbr. 3: paa 250,850 . (H. ${ }^{31}{ }_{12}$ ). De forstnornte Milliontal er altsaa for store.

Det var alligevel en ivrig Virksomhed med store Midler, der bragte mange Mennesker i Afhængighed af tysk Kapital. Det kunde ikke gaa upaaagtet hen fra dansk Side. Den ${ }^{24} / 1$ oprettedes da "L a n d e varnet" (H. ${ }^{2} ;{ }_{1}$ ) Jer straks fik Tilslutning fra hele Landet. (H. ${ }^{20} / 1$ Grv. 93) og 1 Lohet af faa Dage naaede op over en halv Million ( $\left.\mathbf{H} .{ }^{31}{ }_{1}\right)$ aabnede Kontor i Tinglev (H. 1/2, ${ }^{2} / 2$ ) og tog ivrigt fat paa at hjalpe. Inden 14 Dage var der alene i Sonderjylland tegnet over $1 / 4$ Million i Indskud. (H. ${ }^{7} / 2,{ }^{10} / 2,{ }^{21} / 2$ ). Ogsaa Norden Aa tegnedes store Belıb. Alene "Berlingske Tidendes havde inden en Maaneds Forlob indsamlet 497,000 Kr. (1I. ${ }^{23} / 2$ ) og der var ialt indhetalt 722 , 010 til "Landevarnetus Kontor. (H. ${ }^{24} / 2$ ). Da "Landeværnet" holdt sin forste Generalforsamling, var der alene i Sønderjylland tegnet 240,000 af 1600 Medlemmer (H. $2 / 3$ ) og 3 Maaneder seners havde det ydet Stotte $\mathrm{i}$ over 300 Tilfalde. (H. $\left.{ }^{13} / 6\right)$. Nidt i August havde det udlaant $1 \frac{1}{4}$ Million til 400 Laanere (H. ${ }^{28}(\mathrm{~s})$, og inden Aarets L'dlwh havde det anvendt 1.6 Millioner. (H. ${ }^{3} / 12$ ).

For at imndegaa den Nud, der raadede her i Landsdelen, isur i Landbruget, vedtoges der nogle Love, der paa ny stillede betydelige Midler til Raadighed (H. ${ }^{22} / 2,{ }^{23}:$, "2 (riv. S. (f:). Ved dem oprettedes et Hypoteklaanefond (H. $\left.27,{ }^{24}{ }_{1}\right)$, der hurtiut fik en Mangde Begaringer om Laan (u(x) paa 7 Mill. Kir.), mens Laane'kassen, der paa ny sattes $i$ V'irksomhed, samtidig flk $8(0)$ Andragender, hroraf $3(0) 0$ hevilgedes (H. ${ }^{30} 4,2 / 7$ ). Hypoteklaanefondet, der naturligvis ogsaa gav Laan til Tyskere (II. ${ }^{20}$ 10) bevilgede i I.obet af faa Maaneder Laan til ef Beloh af a. 4 Mill. Kr. 
Haderslev Banks Omsætning gik i 192688 Mill. ned og udgjorde 305 Mill., men Indskuddene i den var vokset $281.000 \mathrm{Kr}$. $\left(\right.$ H. $\left.{ }^{2 \times}{ }_{2}\right)$. Desvarre kom Tonder Landmandsbank i Vanskeligheder og matte afskrive hele sin Aktiekapital og 1(K),000 af Præferenceaktiekapitalen, ialt 1.1 Mill. (Av. ${ }^{10} / 4,{ }^{13}$ ). Den blev derefter rekonstrueret. idet der af Bankerne tegnedes 800,000 ny Kapital til de $200,\left(\right.$ (K), der var tillage (H. $\left.{ }^{11} / 4,12 / 4\right)$. Direktsır for den blev L. R. Bylijerg (Av, $7 / 7$ ).

I nd s k u d d e n e i Banker og Sparekasser har været i glædelig Vækst. I Haderslev Bank staar 8,508,713 Kr. (H. ${ }^{28} / 2$ ), i Aabenraa Amts 5 Sparekasser 5,180,250 Kr. paa 4.477 Konti (H. 184) i Sonderborg Amts 7 Sparekasser $14,275,248 \mathrm{Kr}$. paa 12,258 Konti (H. ${ }^{10} / 4,{ }^{30}, 7$ ). Fras- og halrslund Herreders Sparekasse havde $200,000 \mathrm{Kr}$. Fremgang i Indskud ( $\mathrm{H}^{20}{ }^{20}$ ), Sonderborg Sparekasse 881,000 (H. ${ }^{19} / 7$ ). Sparekasserne i Aabenraa Amt 373,000 (H. ${ }^{29} / \mathrm{s}$ ), Haderslev Amts Sparekasse $226,(00)\left(\mathrm{H}^{3}{ }^{30} / \mathrm{s}\right)$. I det hele er Indskuddene i Banker og Sparekasser fra Dec. 24-Dec. :6 rokset med 3,9 Mill. (H. ${ }^{\mathbf{3 0}} / \mathbf{1 2}$ ) og mens der ${ }^{\mathbf{3 1}} / \mathbf{3}$ indestod $\mathrm{i}$ Sparekasserne 1924 30,2 Mill., $26 \quad 36,2$, var der $31 / 327$ godt 41 Mill. (II. ${ }^{31}{ }_{12}$ ).

Et barnagtigt Forsog paa al lave Penge gjorde Corn. Petersen med sine S. O. S. Sedler, da Selvstyrekassen var tom $\left(\right.$ H. $\left.{ }^{7}, \mathrm{~B}\right)$.

Sparekassen for Aabenraa By nedsætter R e n te n (H. $\left.{ }^{30} / 4\right)$.

Sonderjyllands Kreditforening ydede $\quad 26 / 27552$ Laan paa tilsammen $8,418,700 \mathrm{Kr}$. (H. ${ }^{22}{ }^{10}$ ).

Til Bolighyggeriet ydede Danmarks Hypotekhank godt 3 Millioner Kr. (H. $7 / 8$ ).

I 1925 s o lg tes i Sønderbong Amt 6 Gaarde med tilsammen 133 ha (31 Tonder Hartkorn) for 11,723 Kr. pr. Tonde Hartkorn, mens de var vurderet til $9,074 \mathrm{Kr}$. (H. ${ }^{30 / 3}$ ).

Sidst i April foretoges Valg til Akkordudvalgene (H. ${ }^{28}{ }_{4}$ ).

ค) sam kvem.

De A m t sbaner, der endnu er i Drift, kæmper haardt for Tilvarelsen. Bedst stillet or de alsiske. De har ganske vist givet et Underskud af 79,33$) \mathrm{Kr}$. naar Forrentningen regnes med, men selve Driften har eller's givet $13,100 \mathrm{Kr}$. Overskud $\left(\mathrm{H} .{ }^{39} / 6\right)$. (iælden ventes afbetalt 
i $25-30$ (t Aar. $\left(\mathrm{H} .{ }^{17} / \mathrm{H1}\right)$. Værre tynger Haderslev Amitshaners Underskud, der er steget til $465,(0) 0$ og i Aarene siden Genforeningen er kommet op til 3,144,224 Kr., skønt de i Drift er tredje billigste $i$ hele Landet. Trods Underskuddet er der mest Stemning for at drive dem videre, da der kun kunde vindes $80,000 \mathrm{Kr}$. aarlig ved at nedlægge dem $\left(H .{ }^{19} / 1\right)$. I Efteraaret satte Ledelsen en Rakke Mroder rundt om i Amtet i Vark for at drage Fardslen ind til Banerne igen (H. ${ }^{10 / 10}$ ).

Af statsbanerne indviedes den fra Rodekro til l.ogumkloster (H. 3/10). Brobygningen over Alssund skrider godt fremad (H. ${ }^{16 / 5}$ ).

Aahenraa R u tebilse Is k a b afsender og modtager nu daglig 31-33 Vogne. Det har i 26 befordret 53,275 Personer og har $14,714 \mathrm{kr}$. Overskud $\left(\mathrm{H} .{ }^{3} / 3\right)$. Færgen Aarosund Assens har givet lidt Underskud (H. ${ }^{2 \pi} / 5$ ).

Paa $\mathrm{I}$ a $\mathrm{n}$ d e v e j e $\mathrm{n}$ e viser Tællinger stærkt voksende Færdsel. (H. ${ }^{30} / \mathrm{s}$ ). Der ofres da ogsaa meget paa dem. Tonder Amt f. Eks. har siden 1920 aarlig brugt 1.460,000 Kr. gennemsnitlig til sit Vejva'sen. (Av. $\left.{ }^{31 / 3}\right)$. Den ny Amtsrej fra sinderborg til Norhorg blev færdig og taget i Brug. (H. ${ }^{10 / 8}$ ).

D $x$ mingen til sild, der nu leder Fardslen til Gen uden om dansk Omraade, blev færdig, og indviedes ${ }^{1}$ (H. $\left.{ }^{31} /{ }^{3},{ }^{2}, 6 \mathrm{Av} .{ }^{24}{ }_{5}{ }^{31},{ }^{3}\right)$ Den har kostet $: 0$ Mill. Mk. (H. ${ }^{21 / 3}$ ).

\section{Kommunale Forhold.}

Af alle kommunale Forhold interesserer ingen saa almindeligt som $\mathbf{S}$ a t t e $\mathrm{r}$ e. Heldigvis var de nedadgaaende $i$ de fleste af Byerne. Skatteudskrivningen nedsattes i Aabenraa med 133,000 Kr. (H. ${ }^{10}{ }_{1}$ ) og Skatteprocenten hlev uforandret $8,5 \%$. (H. ${ }^{30} / 3$ ). De to Tal er for IIaderslev 108,000 (H. ${ }^{5 / 3}$ ) og $8,4 \%, 0,3$ Nedgang, (H. ${ }^{24} / 3$ ), Smderborg :2(0,010\% og 9.8\%, 1,1 Opgang. (H. $\left.{ }^{8 / 3}\right)$. I Tonder steg Udskrivningen med 15,000 og Skatteprocenten fra 8,8 til 11,6. Indtagterne var her gaaet $20 \%$ ned, (H. ${ }^{2} / 4$ ) i Haderslev $7 \%\left(\mathrm{H} .{ }^{24} / 3\right)$, i sunderborg $20 \%$. (H. $\left.{ }^{24}{ }_{3}\right)$. I Aabenraa med 1,2 Millioner. (H. ${ }^{26} / 3$ ). Ogsaa Landkommunernes Skatter or gaaet ned, i Haderslev Amt med 545,440, (H. 
$20 / 3$ ), derimod er Amtets Udskrivning steget med 300,000 Kr. (H. ${ }^{20} / 11$ ). Gælden er ellers tyngende nok. Aabenraa har 4,078,401 Kr. (H. ${ }^{7} / 2$ ) Tronder har bragt sine Laan ned fra 3,9:6,500 til 2,339,371. (Av. ${ }^{18} / 2$ ). Aabenraa Amt har kun 806,250 Kr. (H. ${ }^{15}{ }_{3}$ ). Haderslev Amt 3,1 Mill. (H. $\left.{ }^{20} / \mathrm{s}\right)$.

\section{Menighedsliv.}

Den Kommission, der var nedsat vedrørende S a mme $n l æ g n$ inge $n$ af Præsteembeder, foreslaar ikke mindre end 21 Sammenlægninger i Sonderjylland og Ophævelse af det ene Embede i Skærbæk. (H. ${ }^{27} / 1$ ).

I Besættelsen af Embederne er der bl. a. sket folgende Endringer: Pastor Matthiesen i Haderslev tager sin Afsked (H. $\left.{ }^{25} / 4\right)$ og Pastor Pedersen udnævnes til Prast ved Frue Kirke. (H. ${ }^{15 / 8}$ ) Pastor Quistgaard kaldes til Fjelstrup (H. ${ }^{20} / 4$ ) og Pastor Tonnesen holder sin Afskedspradiken i Hoptrup. (H. ${ }^{27} / 8$ ).

Menighedsraadenes Sammenslutning arbejder for Tiendeaflosning. (H. ${ }^{10 / 5}$ ).

\section{Oplysning.}

En ny Sk o le indviedes i Skovhuse (Ronhave). (H. 4/5). I Logumkloster vilde man lade Skolerne benytte Forsamlingshuset som Gymnastiksal. Tyskerne vilde imidlertid ikke lade deres Børn gaa derhen. De over saa i en Hotelsal. (H. ${ }^{20} / 10$ ). Graasten Landbrugsskole har i de 3 første Vintre haft ca. 100 Elever. (H. ${ }^{21} / 7$ ).

I Aabenraa Amt var der 4758 skolepligtige Barn mod 5130 Aaret $\mathrm{f}(\mathrm{r}$, deraf gik $\mathbf{4 1 3 0}$ i danske Klasser. I Privatskoler og hjemme undervistes 222 paa Dansk og 364 paa Tysk. 40 dansksprogede Skoler har Tyskundervisning for 1512 af 3042 Born. Der er tyske Privatskoler i Aabenraa, Bedsted, Bov, Graasten, I.ajt og Ige. (H. $7 / 4$ ).

I Tonder Amt findes 100 offentlige Skoler, deriblandt 19 tyske Skoleafdelingrr. Af de 109 Lærere og Larerinder har 63 tysk Uddannelse. Der findes 4865 skolepligtige Born $\bmod 6551^{31} / 1222.4040$ gaar $\mathrm{i}$ offentlig, 225 i private Skoler. I de 19 tyske offentlige Skoler gaar 903 , i de 5 pri- 
vate 80 Elever. De tyske Elever udgur samme P'rocentdel som hele Tiden siden 1922. (H. ${ }^{11 / 4}$ ).

I Sonderborg Amt er der 52 danske Skoler og 3 tyske. Af de 151 Lærere er 61 tyskuddannede. Af de 4:330 Børn gaar 3980 i dansksprogede Klasser. Tysksprogede Afdelinger findes i Augustenborg, Broager og Stinderborg. (H. ${ }^{11 / 4}$ ).

I Haderslev Amt er der 106 Skoler, deraf 2 tysksprogede, 7276 Børn (hvoraf 460 i tyske Skoler) mod 9454 i 1921. Det tyske Antal er 5,8 \% mod 6,2 i 1921 . (H. ${ }^{10} / \mu$ ).

Den danske Skole i Tonder har saamange Børn at begynde med som aldrig f $x$, nemlig 62 . (Av. $5 / 7$ ).

Sønderjydsk Larerforening udtaler Onske om at faa Amtsskolekonsulenterne fast ansat. (Av. ${ }^{16} / 6$. H. ${ }^{20} / 7$ ).

Fra Tonder S e m i n a r dimitteredes 25, f'a Haderslev 27 Larere. (H. ${ }^{17} / 6,{ }^{20} / 6$ ).

Af $s$ t ude nter dimitteredes 21 fra sonderborg, 27 fra Haderslev, 10 fra Tander og 9 fra Aalenraa. (H. ${ }^{28} / 6$, $\left.{ }^{30} / \mathrm{o}\right)$.

Tunder B ibli ot e k har udlaant 27,807 Eind (Av. $3 / 2$ ), Landsbiblioteket 61,363 (II. ${ }^{8 / 5}$ ), i Słnderhorg 35,625, (H. ${ }^{12} / \mathrm{s}$ ), Haderslev 50,625 (H. 8/11). Bibliotekerne har henholdsvis $5,750,19,037,12,750$ og 9,036 Bind. (H. ${ }^{15} / 11,{ }^{26} / \mathrm{s}$ ). Statstilskuddet til alle sonderjydske Biblioteker var $67,905 \mathrm{Kr}$. (H. ${ }^{17} / 8$ ).

Historisk Samfund for Sønderjylland, der har 582 Medlemmer, kravede paa sit Aarsmode det sunderjydske Arkivdepot omdannet til L a n d s a r k ir. (H. $\left.{ }^{12} / 9\right)$. Nogle og fyrre Historikere statter senere Tanken og opfordrer Undervisningsministeren til at sætte Omdannelsen i Værk hurtigst muligt. (H. ${ }^{10} / 10$ ).

Kloppenborg Skrumsagers Stykke "Landevarn" spilledes ${ }^{23} / 9$ første Gang. (Av. ${ }^{25 / 9}$ ).

\section{Ret og Forvaltning-}

Blandt Retssager af mere eller mindre almen Interesse kan nævnes Cornelius Petersens Fornærmelse 
mod Statsminister Stauning. Han var bleven idnmt $2(\% 0)$ Kr. i Bøde, som Hojesteret stadfæstede. (H. ${ }^{11 / 3},{ }^{11} / \mathrm{s}$ ). Han blev ${ }^{2} / 7$ indsat til Afsoning (H. $\left.{ }^{2}{ }^{2}\right)$ men under stor Demonstration den sat paa fri Fod, efter at Bøden var betalt. (H. 4/r). Han var ogsaa indviklet i Jørgen Petersens Støvleaffære, i hvilken denne blev frikendt for falsk Forklaring. $\left(\mathrm{H} .{ }^{11} / \mathrm{s},{ }^{16} / \mathrm{s},{ }^{10} / 7\right)$.

I April angreb en Selvstyremand, Thomsen paa Skovgaard ved Graasten, Kongens Foged efter en Tvangsauktion. (H. $\left.{ }^{9},{ }^{11} / 4\right)$. Corn. P. havde ophidset ham til det. (H. ${ }^{12} / 4$ ). Thomsen fik 4 Maaneders Fængsel. $\left({ }^{30 / 4}, 8 / 8\right)$.

Ved en Skyttefest i Hojer fornærmer Lærer P e te r$\mathrm{s}$ e $\mathrm{n}$ en Politibetjent. (Av. ${ }^{27} / 7,{ }^{12} / \mathrm{\beta}$ ). Han idømtes derfor 60 Dages Fængsel flere andre fik mindre Fængselsstraffe (H. $\left.{ }^{7} / 10\right) \quad$ og blev suspenderet. ( $\mathrm{H} .{ }^{7} / 11$ ).

Nogle Arbejdslıse i Haderslev overfaldt et Par Byraadsmedlemmer paa Gaden (H. $\left.{ }^{15} / 2,{ }^{10} / 3^{3},{ }^{12} / 3\right)$ og blev idømt Boder fra $25-100 \mathrm{Kr}$. (H. $\left.{ }^{13 / 4},{ }^{20 / 4}\right)$.

Vogelgesangs Forkøbsret til de Ejendomme, han satte Penge $i$, blev underkendt ved Retten. (H. ${ }^{27} / \mathrm{s}$ ).

Der fremsættes Forslag om, at Ordenspolitie $\mathrm{i}$ Sønderjylland skulde overtages af Kommunerne. (H. ${ }^{23} / 8$ ). Den nuvarende Ordning bibeholdes imidlertid til 1936. (H. $\left.{ }^{15} / 10\right)$.

En Overgendarm lod sig henrive til at true Kongens Foged med Vaaben. $\left(H .{ }^{2 H} / 0\right)$. Han id ${ }^{\prime \prime}$ mtes $300 \mathrm{Kr}$. i Bøde. (H. ${ }^{10}{ }^{\prime},{ }^{14} / 8$ ).

\section{Personlige Forhold.}

Pastor Tolderlund Hansen i Fjelstrup døde ${ }^{17} / 1$. Møller Jacobsen i Brons 1/2. Lorenz Jepsen i Valsbol 18/2. Hans Ludvigsen i Nybøl ${ }^{2}$ 's. Tandlæge Axel Carstens i Hørsholm $2 / 4$. Landsretspræsident Ricard i Sønderborg $5 /$ s. Lektor Langla i Tonder ${ }^{25}$ /4. Skibsrheder $P$. Marsk Moller i Svendborg ${ }^{\theta} / 2$. Fru Cathrine Stamp i Ullerup ${ }^{20} / 8$. Frk. Alexandra Johannsen i Flensborg ${ }^{20} /$ s. Maler A. P. Sørensen i Rødding ${ }^{18}$ '11. Marie Jensen i Haderslev ${ }^{22} / 11$.

${ }^{22} / \mathrm{s}$ fejrede J. H. Schmidt, Vojensgaard, 70 Aars Fødselsdag, ${ }^{10} / 11$ blev Erich Schlajkier 60 Aar. 
11. Andre Sager.

H. V. Clausen fortæller om Jordkampen. (H. $\left.{ }^{31}{ }_{1}\right)$. Olgerdiget i Uge Sogn findes. (H. ${ }^{1}$ o, ${ }^{9} / 6,{ }^{2} / 11$ ). J. P. Junggreens 1(K) Aarsdag. (H. $\left.{ }^{13 / \mathrm{q}}\right)$. 